\title{
Media frenzy
}

\section{マスメディアの暴走と科学}

Nature Vol. 459(484)/28 May 2009

化石発見の誇大報道は、メディアの潜在的な危険性を浮き彫りにしている。

保存状態がきわめて良好な 4700 万年前の霊長類化石に関 する論文が 5 月 19 日に発表された（http://tinyurl.com/ oycvo8 参照)。ニュースは最初 The Daily Mail 紙にささ やかに報じられたが、その後話が急に大きくなり、おびた だしい数の報道がなされた。

通常、この論文 (J. L. Franzen et al. PLoS ONE 4, e5723；2009）クラスの内容の場合、一部の霊長類化石ほ どの論争は起こらない。今回ドイッのメッセル付近で発掘 された新種の化石 Darwinius masillae は、同じ発掘現場 から出土した他の霊長類化石（ただし断片的な化石）と近 緑関係にあると考えられる。断片化石はアダピス科という 霊長類の絶滅種に属し、高等霊長類とヒトが含まれる直鼻 猿亜目よりも、キッネザルなどが含まれる原猿亜目に近い。 したがって、今回の新種化石もヒトの祖先種とはほとんど 関係がないと見られる。

実際、論文の中で著者は、D. masillae は「のちに類人 猿霊長類へと進化する基幹グループに属している可能性は あるものの、その点を本論文で主張するつもりはなく、ま たD. masillae やアダピス科が類人猿だとも考えていない」 と明確に述べている。さらに、この発見によって霊長類の 進化に関する現在の考え方が変わる、と主張することも避 けている。

ところが、今回の論文発表は通常と異なっていた。 PLOS ONE 誌に投稿される前から、Atlantic（米国ニュー ヨーク）という制作会社が、この発見に関するテレビ用ド キュメンタリー番組と本の制作を進めていた。そして論 文発表からわずか 1 週間後に、本が出版され、ドキュメ ンタリー番組が米国のヒストリーチャンネルと英国 BBC、 ノルウェーNRKで放映された。

本のタイトルにもドキュメンタリー番組のタイトルにも 「つながり (The Link)」という思わせぶりな言葉が使わ
れた。また、この化石が初めて正式発表されたニューヨー クでの記者会見に伴うプレスリリースには、これまでの理 解が一変するという主張が書かれていた。ヒストリーチャ ンネルのウェブサイトではこの化石が「人類の祖先」とさ れ、 $\mathrm{BBC}$ のエブサイトでは「人類の最も古い祖先」と 説明されていた。

公平を期するために言うと、記者会見での著者の主張は、 適切に慎重になされた。しかし著者は、ドキュメンタリー 番組とマスメディアのキャンペーンに深く関与しており、 大胆な不実表示との結びつきは否定できない。

もう 1 つ問題を投げかけたのは、論文発表が、記者会 見と当初のマスコミ報道に間に合わなかった点である。そ のため、研究チーム以外の科学者が研究内容を評価できず、 ジャーナリストが研究についてバランスのとれた記事を書 く環境も整つていなかった。

PLOS ONE 誌の編集者と査読者が、この論文について 職務を果たさなかったわけではない。ただし、論文投稿時 に時間的余裕がなくなっていたのは確かである。Nature でも、時々、テレビ用ドキュメンタリー番組と関連した論 文の投稿の申込みを受けるようになって久しく、そうした 申込みには通常、放送日が記載されている。Natureでは、 査読過程が損なわれる恐れがある場合、必ず論文を却下し てきた。時間的余裕がないと、査読によって問題が表面化 し、論文揭載が遅れたり不受理となっても、番組が予定通 り放送されてしまう危険性があるからだ。

原則として、科学が、意欲に満ちあふれる報道機関と手 を結ぶことを否定する理由はない。しかし実際には、その ような連携には相反する動機が生じ、その結果、科学をき ちんと評価して伝達するという過程が、あつけなく崩れ去 る危険性がある。この点は見逃してはならない。(菊川要 訳) 